WIDER Working Paper 2019/28

Can a wage subsidy system help reduce 50 per cent youth unemployment?

Evidence from South Africa

Amina Ebrahim ${ }^{1}$ and Jukka Pirttilä ${ }^{2}$

March 2019

United Nations University World Institute for Development Economics Research

wider.unu.edu 
Abstract: The paper examines the incidence and employment impacts of the Employment Tax Incentive, a South African wage subsidy system that is targeted at the employers of low-wage youth. The paper uses a triple differences strategy and survey and administrative data, covering the universe of South African workers. The results reveal that the system has not had a positive influence on the employment rate of eligible workers. The number of jobs in the region where the subsidy is the greatest has increased, but the increase is not statistically significant, perhaps due to a low take-up rate. Earnings seem to have increased for part of the eligible group, suggesting that the incidence is partly on workers.

Keywords: employment, taxation, youth employment, wage subsidies JEL classification: H24, J23, J28, H40, O12

${ }^{1}$ UNU-WIDER, Pretoria, South Africa, corresponding author email: amina@wider.unu.edu; ${ }^{2}$ University of Helsinki, VATT, and UNU-WIDER. Helsinki, Finland.

This study has been prepared within the UNU-WIDER project on 'Southern Africa - Towards Inclusive Economic Development (SA-TIED)'.

Copyright (C) UNU-WIDER 2019

Information and requests: publications@wider.unu.edu

ISSN 1798-7237 ISBN 978-92-9256-662-3 https://doi.org/10.35188/UNU-WIDER/2019/662-3

Typescript prepared by Lesley Ellen.

The United Nations University World Institute for Development Economics Research provides economic analysis and policy advice with the aim of promoting sustainable and equitable development. The Institute began operations in 1985 in Helsinki, Finland, as the first research and training centre of the United Nations University. Today it is a unique blend of think tank, research institute, and UN agency_providing a range of services from policy advice to governments as well as freely available original research.

The Institute is funded through income from an endowment fund with additional contributions to its work programme from Finland, Sweden, and the United Kingdom as well as earmarked contributions for specific projects from a variety of donors.

Katajanokanlaituri 6 B, 00160 Helsinki, Finland

The views expressed in this paper are those of the author(s), and do not necessarily reflect the views of the Institute or the United Nations University, nor the programme/project donors. 
South Africa has a serious youth unemployment problem, with an unemployment rate of more than 50 per cent in the 15-24 age category. One of the main policy instruments that the government has used to combat youth unemployment is a wage subsidy system, called the Employment Tax Incentive (ETI). The policy was introduced in 2014 and is a tax credit targeted to the employers of young (below 30 years of age) and low-wage (below R6,000 a month) workers. The design of the subsidy enables a triple difference evaluation strategy, which this paper utilizes.

The consensus view in the earlier economic work on the impacts of wage subsidies (such as Gruber 1997) suggests that since labour demand is typically more elastic than labour supply, the incidence of wage subsidies (or payroll tax reduction) falls on the employees. This means that earnings rise and the final gross wage cost to the employer is not affected. Hence, employment does not react either. However, recent work on Greece (Saez et al. 2012), France (Cahuc et al. 2018), and Sweden (Saez et al. 2019) indicates the opposite: earnings are not affected and hence the incidence is (mostly) on employers, opening up a way to positive employment impacts.

The literature is still inconclusive about what would be the optimal design for wage subsidies. According to Cahuc et al. (2018:1):

Simulations of counterfactual policies show that the effectiveness of the hiring credit relied to a large extent on three features: it was unanticipated, temporary and targeted at jobs with rigid wages. (Cahuc et al. 2018:1)

On the other hand, Saez et al. (2019:39) conclude that:

Some particular features of the tax cut we study may have enhanced its effectiveness. It was employer borne, salient, administered in a way to ensure nearperfect, immediate and automatic take-up, it targeted young workers but was encompassing (i.e. applied not just to new hires out of unemployment or a subset), it was intended to be permanent, and it was large.' (Saez et al. 2019: 39)

We therefore have no general evidence about whether more targeted or more permanent systems work better.

The paper contributes to the literature by examining the efficiency of wage subsidies in an emerging market context, where the capacity to administer the system (both in firms and within the administration) may be less perfect than in high-income countries. The sheer size of the unemployment crisis also makes evaluating the efficiency of the policy pressing. The maximum duration of the subsidy is 24 months, which means that the system is a hybrid between a (shortterm) hiring subsidy and a more permanent system. It was originally planned to be temporary and last for three years, was subsequently extended for another two years, and has recently been extended for ten more years. We use labour market survey data and the universe of payroll tax data from the South African Revenue Service (SARS) to examine the impacts of the system.

Since the system has been targeted at both low-wage and young workers, we can separate out any differential trends that have affected either young workers or low-wage workers in our triple differences identification strategy. There are some earlier studies evaluating the South African ETI policy. Ranchhod and Finn (2015) compare the development of youth and non-youth employment over time in a difference-in-differences (DD) fashion, but only for the first year after the reform. 
Ebrahim et al. (2017) compare ETI-claiming firms with firms that were eligible but did not take up the policy. Our identification is based on eligibility of workers, i.e. we are mainly interested in the intention-to-treat (IT'T) estimates, which identify the programme impacts, including the part that stems from partial take-up. Ours is also the first study to examine the earnings incidence of the policy. The paper proceeds as follows. Section 2 presents the institutional details of the subsidy. Section 3 introduces our datasets and the empirical strategy. The results from the survey data are presented in Section 4, and the results based on administrative data are available in Section 5. Section 6 concludes.

\section{Institutional framework}

Proposals for a wage subsidy in South Africa were made by Heintz and Bowles (1996) soon after the first democratic election in 1994. Wage subsidies were proposed as part of South Africa's postapartheid growth strategy (Lewis 2001; Pollin et al. 2009).

The ETI, previously called the 'youth wage subsidy', was first conceptualized and proposed by the National Treasury in 2011. In a discussion paper, the National Treasury highlights the need to address the problem of youth unemployment in South Africa. It emphasizes the necessity of a 'multi-pronged strategy to raise employment and support inclusion and social cohesion'. The discussion paper names economic growth and progress in the education system as two important components for solving the problem of youth unemployment.

The motivation behind the ETI lies in the context of large numbers of low or unskilled youths and rigidities in the labour market leading to a situation where the employment of youths is undesirable to firms. The stated aim of the subsidy is to address the low demand for youth workers by reducing the costs, and thereby risks, associated with employing youths. The aim was to target the policy at the age range of workers with the highest unemployment rate, namely those between the ages of 18 and 30 years.

The National Treasury discussion paper reviews ongoing active labour market policies aimed at the youth in South Africa. Sector Education Training Authorities (SETA), Learnership and Technical and Vocational Education and Training colleges (TVET, previously Further Education and Training (FET) colleges) were established to enhance the level of skill and education of the youth. SETAs and TVET colleges have been underfunded and are criticized for the poor management and poor quality of their lecturers (Bernstein et al. 2016). A host of programmes such as the Graduate Development Programme (GDP), Job Preparation Programme (JPP), the National Youth Service, Jobs \& Opportunity Seekers (Jobs), the Graduate Database, and Youth Advisory Centers were established by the National Youth Development Agency (NYDA) to provide job-search and job-matching assistance. The NYDA also hosts many entrepreneurship programmes to provide youths with assistance from the inception to the establishment of a small business.

These labour market policies are aimed at increasing individuals' education or skill levels, or labour supply interventions. This, however, has not always transferred into successful employment for youths (Altbeker et al. 2007). Even if one considers the scenario where youths have higher education and skill levels, the question remains as to whether there are sufficient jobs in the economy to absorb them. If too few jobs exist, then any increase in the skill levels of youths will limit the extent to which they are gainfully employed. 
There have been two interventions aimed at increasing the demand for youth labour. The Expanded Public Works Programme (EPWP) and the Learnership programme. The EPWP gives individuals an average of 80 days of work but has not been found to change the future employment probabilities of workers (Altbeker et al. 2007). The Learnership programme provides incentives to firms that train young employees. The majority of those entering the Learnership programme were previously unemployed, indicating that the intervention is reaching the required target group. Visser and Kruss (2009) find that 76 per cent of those registered for high skill-level learnerships are employed two years after first registration, while only 46 per cent of those in the low-skills programme are employed two years later. Enrolment in the low-skills programme is double that of the high skills programme. This means that there is a large group of youths going through the Learnership programme but not finding suitable employment afterwards.

The ETI is similar in design to the Learnership programme. In the Learnership programme, firms can claim a tax subsidy for training workers while employed. Similarly, firms hiring ETI-eligible employees can claim a tax subsidy, but the subsidy relates only to the employment and not the training of eligible workers. Of the previously unemployed on the Learnership programme, 73 per cent are in Learnership programmes at large firms. Very few report being in Learnership programmes at smaller firms. This is thought to be the result of the high costs associated with administering the Learnership programme.

After the implementation of the various programmes discussed above, youth unemployment remains stubbornly high in South Africa. The ETI was proposed in addition to many of the other policies and programmes aimed at youths. The difference is that the ETI aimed to stimulate the demand for youth labour by lowering the relative cost of hiring an inexperienced youth.

Employers of new workers who are no more than 29 years of age and who do not earn more than R6,000 a month qualify for the subsidy. Domestic workers and public sector employees are not eligible. The maximum amount of the subsidy is R1,000, which is paid for earnings between R2,000 and R4,000. The subsidy is thus relatively very large for workers earning R2,000. It is phased in for income below R2,000 and is phased out in the region of R4,000-R6,000. The shape of the subsidy is depicted in Figure 1. The amount of the subsidy is halved during the second year of employment, with a maximum subsidy of R500. The subsidy is not automatic, and the subsidy claim is offset by a monthly reduction in the amount of pay-as-you-earn (PAYE) taxes that the employer needs to pay to SARS. This means that the wage received by the employee is not affected and employees may not be aware that employers are claiming the subsidy for their employment. The policy does not require any training for the employed youths and is available to all industries. No requirements are placed on length of unemployment for eligible youths as is sometimes seen in similar policies in other countries. During the first full year of operation, around 30 per cent of eligible youths benefitted from the system. Individual-level analysis shows that the employers of the youngest workers are more likely to use the subsidy, and the take-up rate among 29-year-olds is, for instance, 12 percentage points less than the average. 


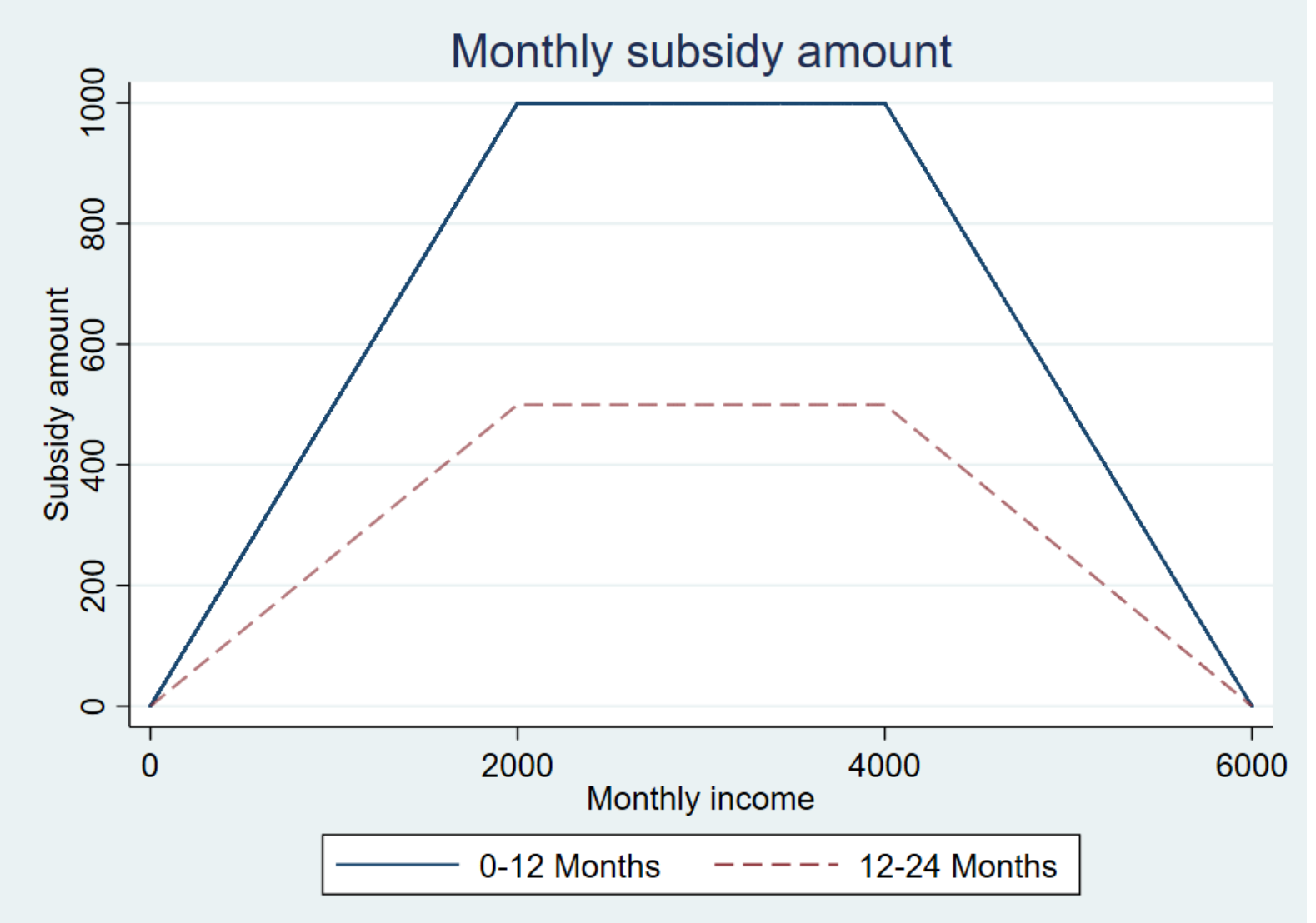

Source: Authors' own estimates.

\section{Theoretical framework}

Wage subsidies can be offered either to the job seeker or to the firm. A subsidy can be claimed by a job seeker once employment has been found. Also known as worker-side subsidies, wage subsidies offered to job seekers aim to increase labour supply in the market and are often seen in developed countries. Such policies include the Earned Income Tax Credit in the United States, Working Families' Tax Credit in Britain, the Self-Sufficiency Project in Canada, and other programmes in Australia, New Zealand, Finland, Ireland, and Belgium (Smith 1993).

Firm-side subsidies are subsidies given to firms when the firm employs individuals eligible for the subsidy. The aim of a firm-side subsidy is to incentivize firms to hire eligible individuals they would otherwise not be interested in hiring. A wage subsidy decreases the cost of employing an individual but without any change in the amount the individual is paid. This allows firms to increase employment of the subsidized group and output, leaving the wages of the subsidized individual unchanged. The elasticity of labour demand and the amount of the subsidy determines the increase in employment at a firm. Of the two types of subsidies, the firm-side subsidy fits the South African context as it deals with the demand for youth labour where the youth labour supply is already high.

In recent years, tax credits have been discussed as a policy tool for reducing the cost of hiring groups with high unemployment rates. The policy discussion in South Africa is simple: targeted tax credits can boost employment of youths. Although firms could potentially pocket the tax credit 
as economic rent or release older workers in order to hire younger workers, the policy includes a penalty to firms found doing this.

A wage subsidy has the potential to increase the demand for labour through the reduction in labour costs at firms. In Figure 2 this is described by the shift to the right of the aggregate demand for labour in the economy from $\mathrm{L}_{\mathrm{D} 1}$ to $\mathrm{L}_{\mathrm{D} 2}$.

Where the labour supply curve $\mathrm{L}_{S}$ is upward sloping the effect of the subsidy will be shared between the workers and the firms depending on the elasticity of labour demand and labour supply. This raises the wages of workers from $\mathrm{W}_{0}$ to $\mathrm{W}_{1}$ and decreases the cost of employment to firms from $\mathrm{W}_{0}$ to $\mathrm{W}_{1}-\mathrm{C}$. The amount of labour demanded moves from $\mathrm{QL}_{0}$ to $\mathrm{QL}_{1}$. We consider the case where labour supply is highly elastic as the unemployment rate in South Africa is high. In the second scenario there is a small increase in wages to workers and a large reduction in the cost of employment to firms. The amount of labour demanded moves from $\mathrm{QL}_{0}$ to $\mathrm{QL}_{2}$, a larger increase than in the first scenario.

Figure 2: Theoretical shift in labour demand due to a wage subsidy

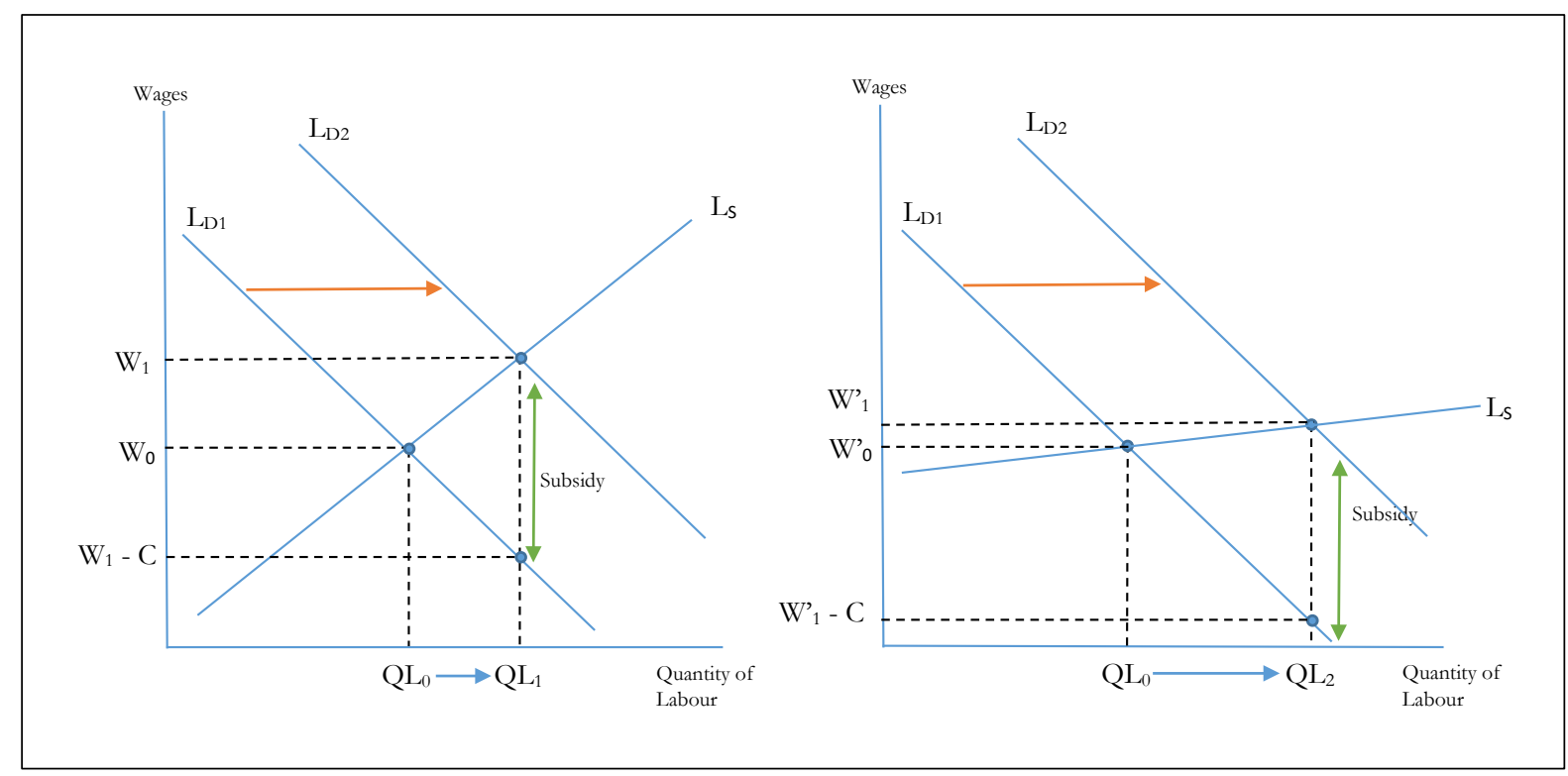

Source: Authors' own figures.

In both scenarios it is expected that the wages of targeted workers will increase.

\section{$4 \quad$ Data}

We use two different datasets to investigate the impacts of the reform. The first is PALMS 3.2, a publicly available dataset from DataFirst at the University of Cape Town (Kerr et al. 2017). The dataset provides consistent and harmonized survey information about employment and wages and is representative of the population. We use years 2000-17 from the dataset. The survey provides information about employment and unemployment rates, and it also has a number of demographic variables.

Another source we use is the administrative tax data, which is based on the PAYE reports (IRP5 forms) by employers to SARS. Through a joint initiative between SARS, the National Treasury, 
and UNU-WIDER, the anonymized tax data from these IRP5 forms were made available for approved research at a secure data facility at the National Treasury in Pretoria.

The data are population wide with detailed information about earnings, as well as the actual ETI use status. However, the administrative data only have information about gender, and have no other demographic characteristics. These data cover the years 2011 to 2016. While all the work contained herein was conducted at the secure data facility, the results are not official statistics and have been created for this research.

The use of administrative tax records is advantageous for the evaluation of the ETI. The subsidy is claimed through a reduction in taxes owed to SARS, which means there are records of these claims for every firm that claimed the subsidy. The subsidy is available to all firms registered for PAYE and the administrative data represent the entire population of PAYE firms irrespective of their claim on the subsidy. The data are panel in nature, which allows us to observe tax-paying individuals before the start of the subsidy and during implementation. Since workers may be unaware of their employers claiming the subsidy, a survey of workers would not provide us with the information we need for this evaluation.

The primary disadvantage of using administrative data is their lack of demographic information and for this reason we chose to use both survey and tax data for our analysis.

\section{$5 \quad$ Empirical approach}

The main approach is to estimate ITT or the impact of being eligible on the subsidy using a triple differences strategy as follows:

$$
\begin{array}{r}
y_{i, t}=\alpha+\beta * \text { youth }_{i}+\gamma * \text { low }_{i}+\delta * \text { after }+\zeta * \text { youth }^{2} * \text { low }_{i}+\eta * \text { youth } \\
* \text { after }_{, t}+\theta * \text { low } * \text { after } i, t+\lambda * \text { youth }^{2} * \text { low } * \text { after } i, t+\epsilon_{i, t}
\end{array}
$$

where $y, t$ is the outcome variable (such as earnings or employment) for individual $i$ in year $t$, youthi is an indicator variable with value equal to one if the individual is at most 29 years old, lowi is an indicator of whether the individual belongs to the low-wage group, and aftertis an indicator which is one for the years after the reform. We are interested in coefficient $\lambda$ of the triple interaction term, youth $*$ low $*$ after $i, t$, which measures the impact of being eligible for the youth wage subsidy system. We also start with a simple double difference strategy, where the interest is about the term youth $*$ after $i$, In this case the analysis examines the impact on all young workers.

The identifying assumption is that there are no differential trends that would have affected young low-wage workers differently than older low-wage workers or higher-wage young workers. Because of the difference-in-difference-in-difference (DDD) approach, we can control for simultaneous changes that affect all young or all low-wage workers.

The challenge in this analysis is that the earnings level is only observed if the individual is working. As a solution to this, in the PALMS analysis we predict income, based on pre-reform data, using a model with age, gender, and years of education as regressors. This approach provides a good predictor of individuals' earnings, since the income levels differ markedly between socioeconomic groups (see Table 1). The lowwage dummy takes a value of one if the predicted income level is greater than the median. Alternatively, we calculate the ETI amount based on the predicted wage. 
Instead of a simple after dummy, we mostly use year fixed effects. To allow for differential trends between groups of workers, we add youth-specific and low wage-specific linear trends to some of the models.

Table 1: Pre-reform shares of youths with wage $<R 6,000$

\begin{tabular}{lllll}
\hline & Africans & \multicolumn{3}{l}{ Non-Africans } \\
\hline Low education & Men & Women & Men & Women \\
High education & 0.87 & 0.93 & 0.67 & 0.84 \\
\hline
\end{tabular}

Source: Authors' own estimates based on the PALMS 3.2 data.

In the analysis using administrative data, we cannot use demographic variables to predict earnings, but the missing earnings problem does not arise, of course, since what is in the data are earnings for those who actually work. While we recognize that the earnings can be endogenous, we use the actual wage rates to divide workers into low-wage and higher-wage categories.

Finally, instead of using a simple ETI eligibility dummy, we use the ETI amount that the person would have (based on predicted earnings) as a regressor as follows:

$$
\begin{aligned}
& y_{i, t}=\alpha+\beta * \text { youth }_{i}+\gamma * \text { eti } i+\delta * \text { after } t+\zeta * \text { youth } * \text { et } i i+\eta * \text { youth } \\
& * \text { after }_{, t}+\theta * \text { et } i * \text { after }_{i, t}+\lambda * \text { youth } * \text { et } i * \text { after } i, t+\epsilon i, t
\end{aligned}
$$

This specification caters for the possibility that the actual monetary amount of the subsidy probably also matters for the employment prospects.

\section{$6 \quad$ Results-based employment and unemployment trends}

We start by examining graphical trends of employment (Figure 3) and unemployment (Figure 4). The series suggests that there appears to have been no trend breaks for the employment rates for the target (or eligible) group of low-wage young workers. The regression results are presented in Tables 2 and 3. The results suggest that there have been no employment gains nor a drop in unemployment for youths or low-wage youths. It therefore appears that there is no robust evidence that the ETI subsidy system has contributed to greater youth employment at the aggregate level. 
Figure 3: Private sector employment rates for 25-35-year-olds. Low-wage status determined on the basis of predicted earnings

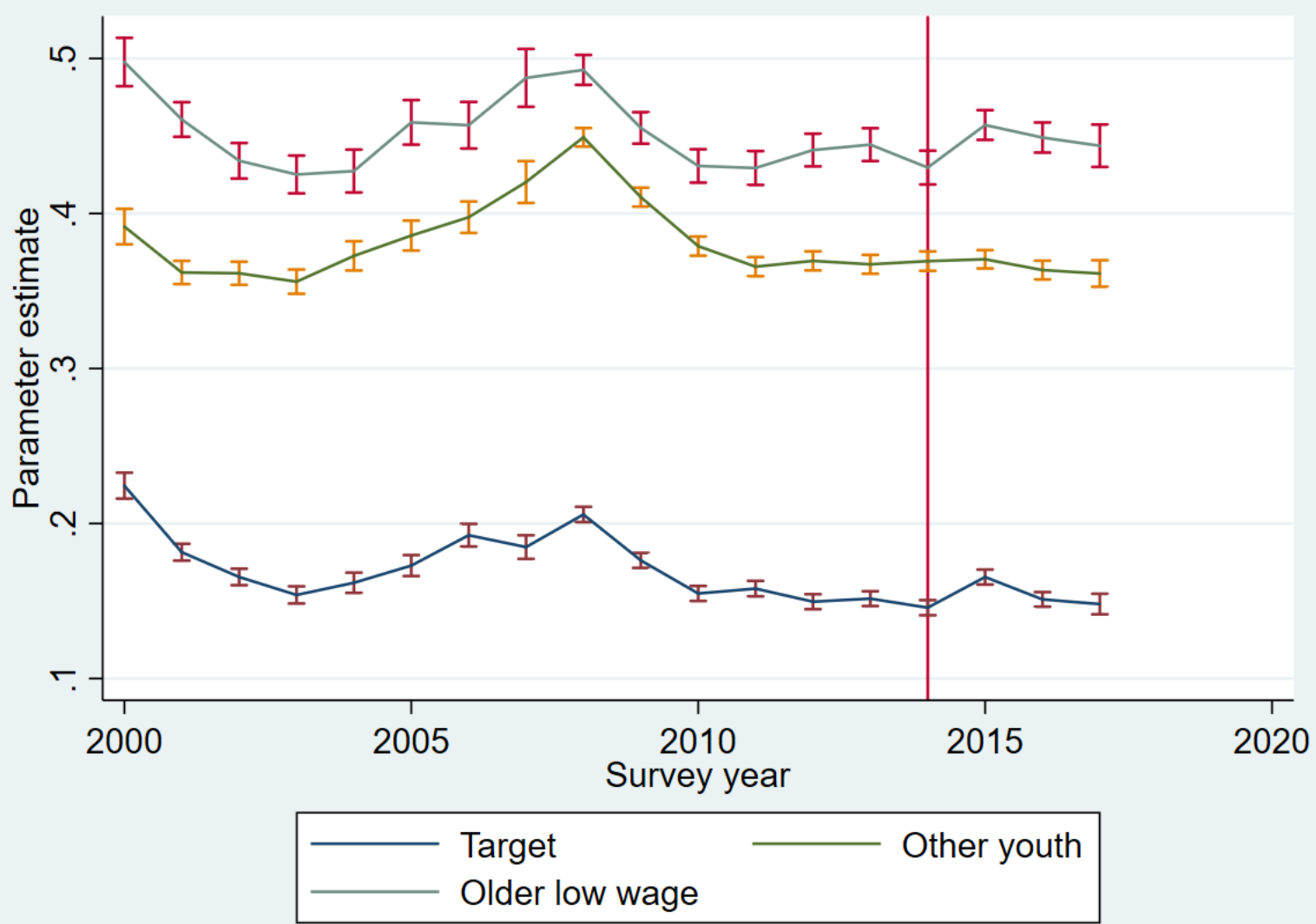

Source: Authors' own estimates based on PALMS 3.2. 
Figure 4: Unemployment rates for 25-35-year-olds. Low-wage status determined on the basis of predicted earnings

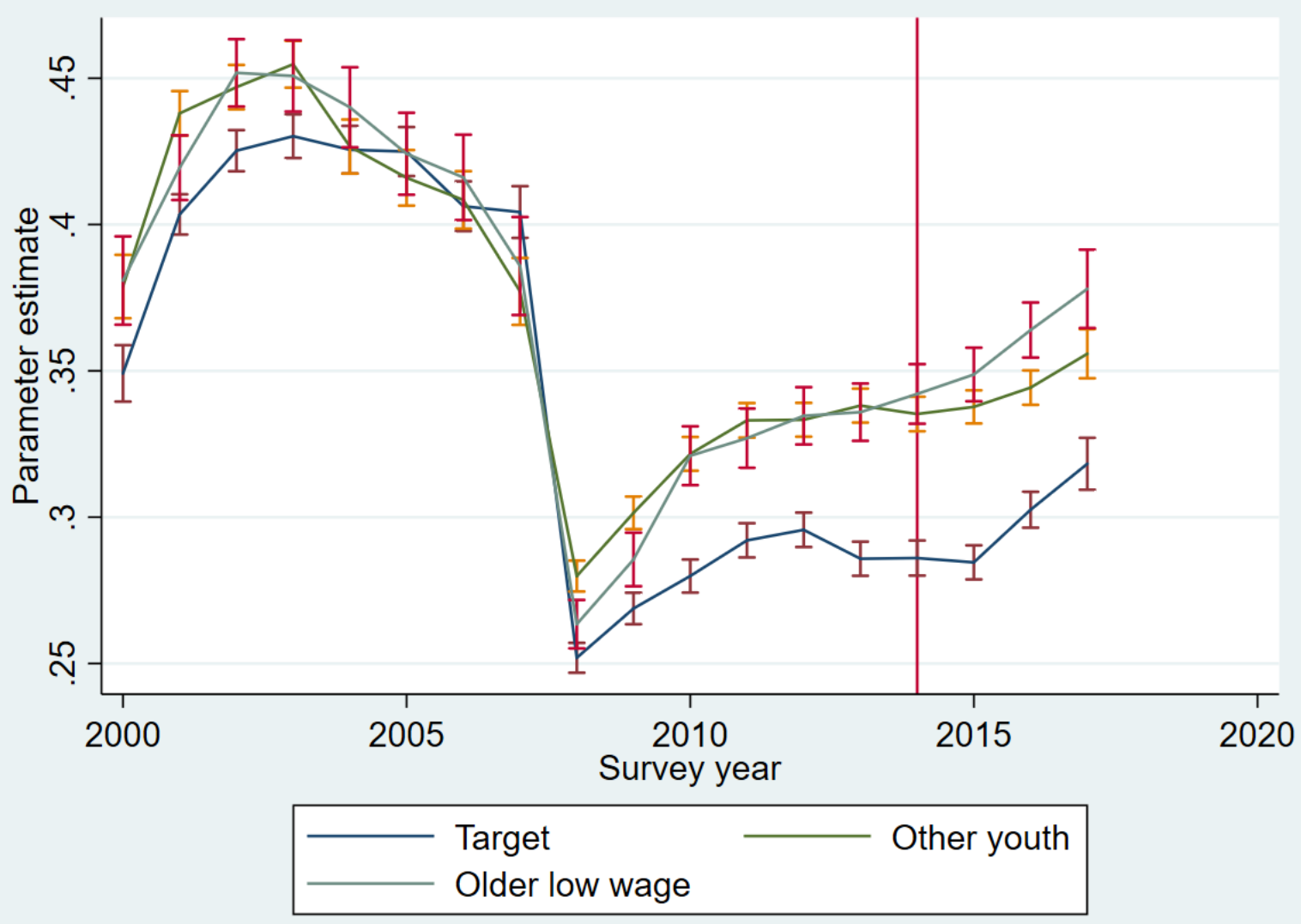

Source: Authors' own estimates based on PALMS 3.2.

Table 2: Estimation results on employment

\begin{tabular}{|c|c|c|c|c|c|c|}
\hline VARIABLES & $\begin{array}{l}\text { (1) } \\
\mathrm{DD}\end{array}$ & $\begin{array}{l}\text { (2) } \\
\text { DD+trends }\end{array}$ & $\begin{array}{l}(3) \\
\text { DDD }\end{array}$ & $\begin{array}{l}\text { (4) } \\
\text { DDD+trends }\end{array}$ & $\begin{array}{l}(5) \\
\text { DDD }\end{array}$ & $\begin{array}{l}(6) \\
\text { DDD }\end{array}$ \\
\hline youth_after & $\begin{array}{l}-0.00159 \\
(0.00225)\end{array}$ & $\begin{array}{l}0.00695^{\star *} \\
(0.00311)\end{array}$ & & & & \\
\hline ETI dummy & & & $\begin{array}{l}-0.00888^{\star *} \\
(0.00442)\end{array}$ & $\begin{array}{l}-0.00900^{\star *} \\
(0.00442)\end{array}$ & & \\
\hline ETI amount & & & & & $\begin{array}{l}-1.91 e-06 \\
(5.49 e-06)\end{array}$ & $\begin{array}{l}-2.20 \mathrm{e}-06 \\
(5.49 \mathrm{e}-06)\end{array}$ \\
\hline Constant & $\begin{array}{l}0.534^{\star \star \star} \\
(0.00243)\end{array}$ & $\begin{array}{l}0.508^{\star \star \star} \\
(0.00203)\end{array}$ & $\begin{array}{l}0.605^{\star \star \star} \\
(0.00138)\end{array}$ & $\begin{array}{l}0.592^{\star \star \star} \\
(0.00248)\end{array}$ & $\begin{array}{l}0.591^{\star \star \star} \\
(0.00274)\end{array}$ & $\begin{array}{l}0.569 * \star \star \\
(0.00263)\end{array}$ \\
\hline Observations & $1,331,747$ & $1,331,747$ & $1,331,747$ & $1,331,747$ & $1,331,747$ & $1,331,747$ \\
\hline R-squared & 0.059 & 0.058 & 0.102 & 0.102 & 0.062 & 0.061 \\
\hline Trends & NO & YES & NO & YES & NO & YES \\
\hline Mean & 0.249 & & 0.137 & & 0.137 & 0.137 \\
\hline
\end{tabular}

Notes: The table presents estimation results where the dependent variable is private sector employment. Lowwage status is based on predicted wages. Columns (1) and (2) present DD estimates and (3)-(6) present DDD estimates. In columns (1)-(4), the estimate is the coefficient of a dummy variable, whereas columns (5) and (6) present estimates for the actual subsidy value. Columns (2), (4), and (6) add group-specific trends to the model. The mean is the mean unemployment rate for the target group (youth in columns 1 and 2 and low-wage youth in columns 3-4). Robust standard errors in parentheses. ${ }^{* \star} p<0.01,{ }^{\star *} p<0.05,{ }^{*} p<0.1$

Source: Authors' own estimates using PALMS 3.2. 
Table 3: Estimation results on unemployment

\begin{tabular}{|c|c|c|c|c|c|c|}
\hline VARIABLES & $\begin{array}{l}(1) \\
\text { DD }\end{array}$ & $\begin{array}{l}\text { (2) } \\
\text { DD+trends }\end{array}$ & $\begin{array}{l}(3) \\
\text { DDD } \\
\end{array}$ & $\begin{array}{l}\text { (4) } \\
\text { DDD+trends }\end{array}$ & $\begin{array}{l}(5) \\
\text { DDD }\end{array}$ & $\begin{array}{l}(6) \\
\text { DDD }\end{array}$ \\
\hline youth_after & $\begin{array}{l}-0.0236^{\star \star \star} \\
(0.00218)\end{array}$ & $\begin{array}{l}-0.00549 * \\
(0.00298)\end{array}$ & & & & \\
\hline ETI dummy & & & $\begin{array}{l}-0.000725 \\
(0.00433)\end{array}$ & $\begin{array}{l}4.95 e-05 \\
(0.00434)\end{array}$ & & \\
\hline ETI amount & & & & & $\begin{array}{l}-6.78 e-06 \\
(5.07 e-06)\end{array}$ & $\begin{array}{l}-6.92 \mathrm{e}-06 \\
(5.08 \mathrm{e}-06)\end{array}$ \\
\hline Constant & $\begin{array}{l}0.329 * \star \star \\
(0.00248)\end{array}$ & $\begin{array}{l}0.384^{\star \star \star} \\
(0.00195)\end{array}$ & $\begin{array}{l}0.276^{\star \star \star} \\
(0.00264)\end{array}$ & $\begin{array}{l}0.313^{\star \star \star} \\
(0.00237)\end{array}$ & $\begin{array}{l}0.250 \star \star \star \\
(0.00267)\end{array}$ & $\begin{array}{l}0.280^{\star \star *} \\
(0.00245)\end{array}$ \\
\hline Observations & $1,331,747$ & $1,331,747$ & $1,331,747$ & $1,331,747$ & $1,331,747$ & $1,331,747$ \\
\hline R-squared & 0.012 & 0.007 & 0.018 & 0.012 & 0.037 & 0.032 \\
\hline Trends & NO & YES & NO & YES & NO & YES \\
\hline Mean & 0.321 & & 0.283 & & 0.283 & 0.283 \\
\hline
\end{tabular}

Notes: The table presents estimation results where the dependent variable is the unemployment rate. Low-wage status is based on predicted wages. Columns (1) and (2) present DD estimates and (3)-(6) DDD estimates. In columns (1)-(4), the estimate is the coefficient of a dummy variable, whereas columns (5) and (6) present estimates for the actual subsidy value. Columns (2), (4), and (6) add group-specific trends to the model. The mean is the mean unemployment rate for the target group (youth in columns 1 and 2 and low-wage youth in columns 3-4). Robust standard errors in parentheses. ${ }^{\star \star \star} p<0.01,{ }^{\star \star} p<0.05,{ }^{*} p<0.1$.

Source: Authors' own estimates using PALMS 3.2.

\section{$7 \quad$ Incidence and labour market transitions}

As above, we first examine the development of key variables using graphical evidence. As we cannot observe employment and unemployment rates in the administrative data, we approach the employment outcome by dividing the data into cells based on gender, age, and R500 wage intervals. We then examine the number of jobs in each cell before and after the reform. We also investigate the response in earnings level to detect the incidence of the subsidy and what happens to new hires; an outcome on which the ETI (since it is very similar to a hiring subsidy) could have the greatest impact.

Figures 5, 6, and 7 present developments for these outcome variables over time. It appears that there are no great changes for the treated groups that would be visible in the graphs. 
Figure 5: Log earnings in groups

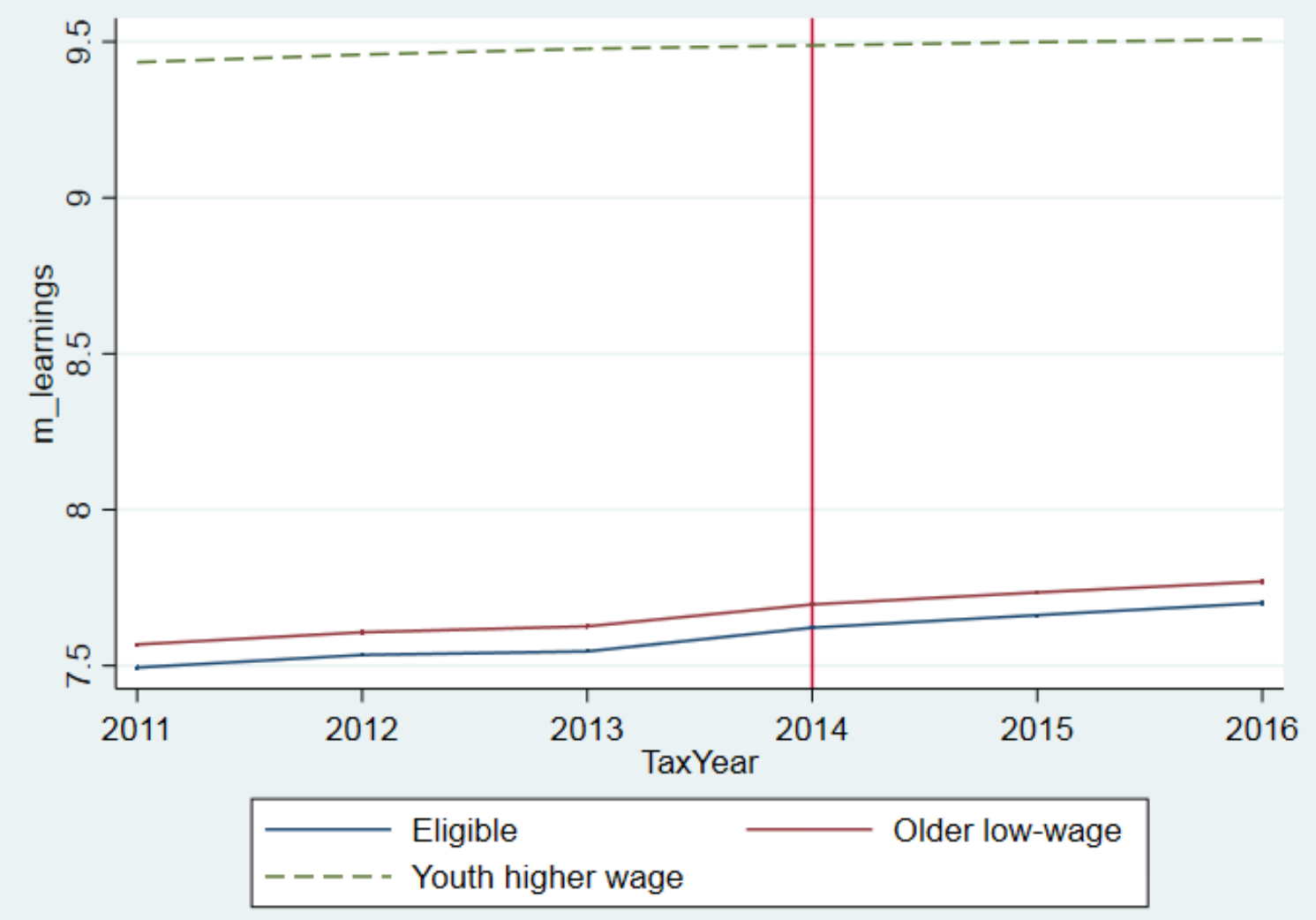

Source: Authors' own estimates using IRP5 data. 
Figure 6: Log number of jobs in cells

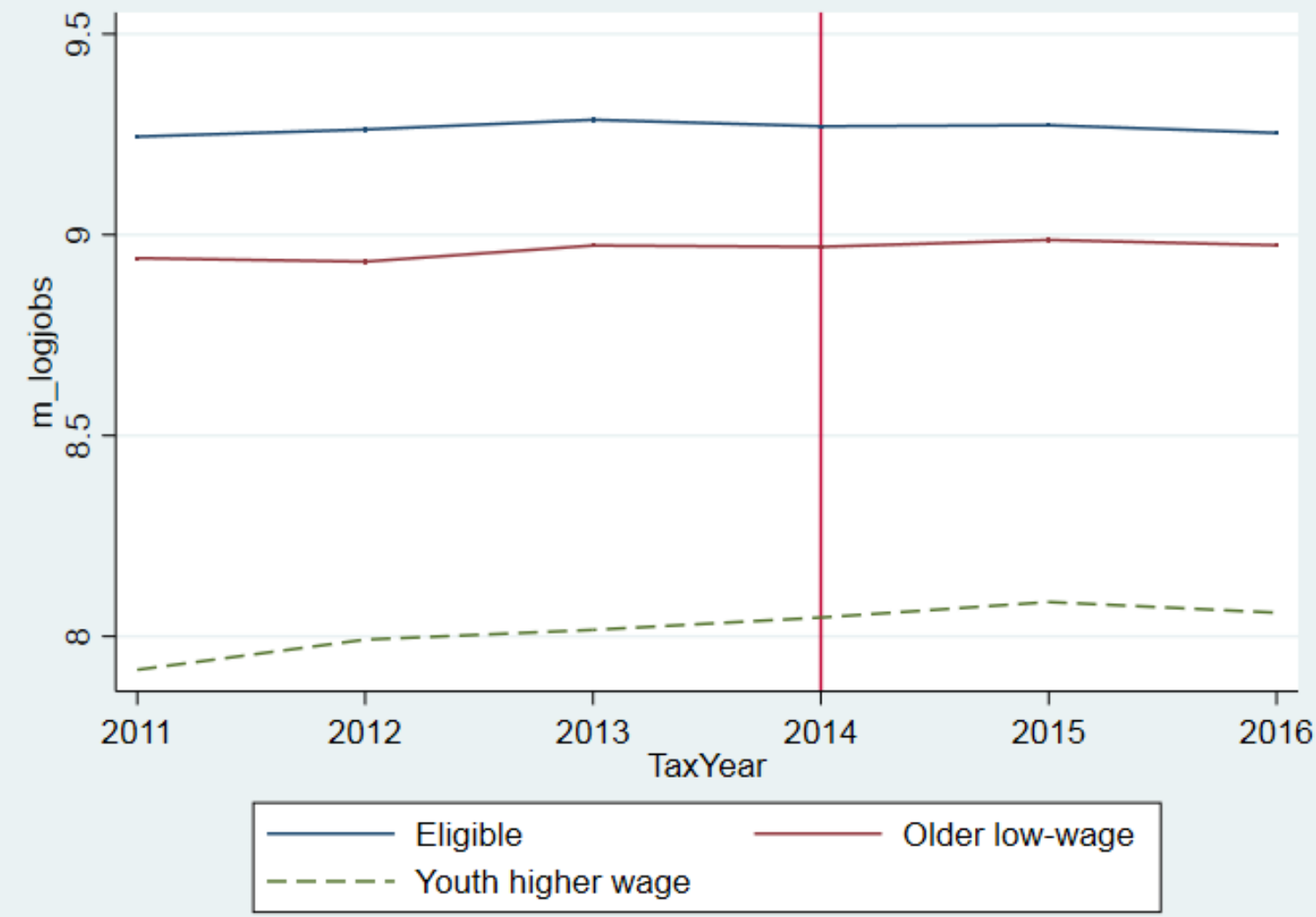

Source: Authors' own estimates using IRP5 data. 


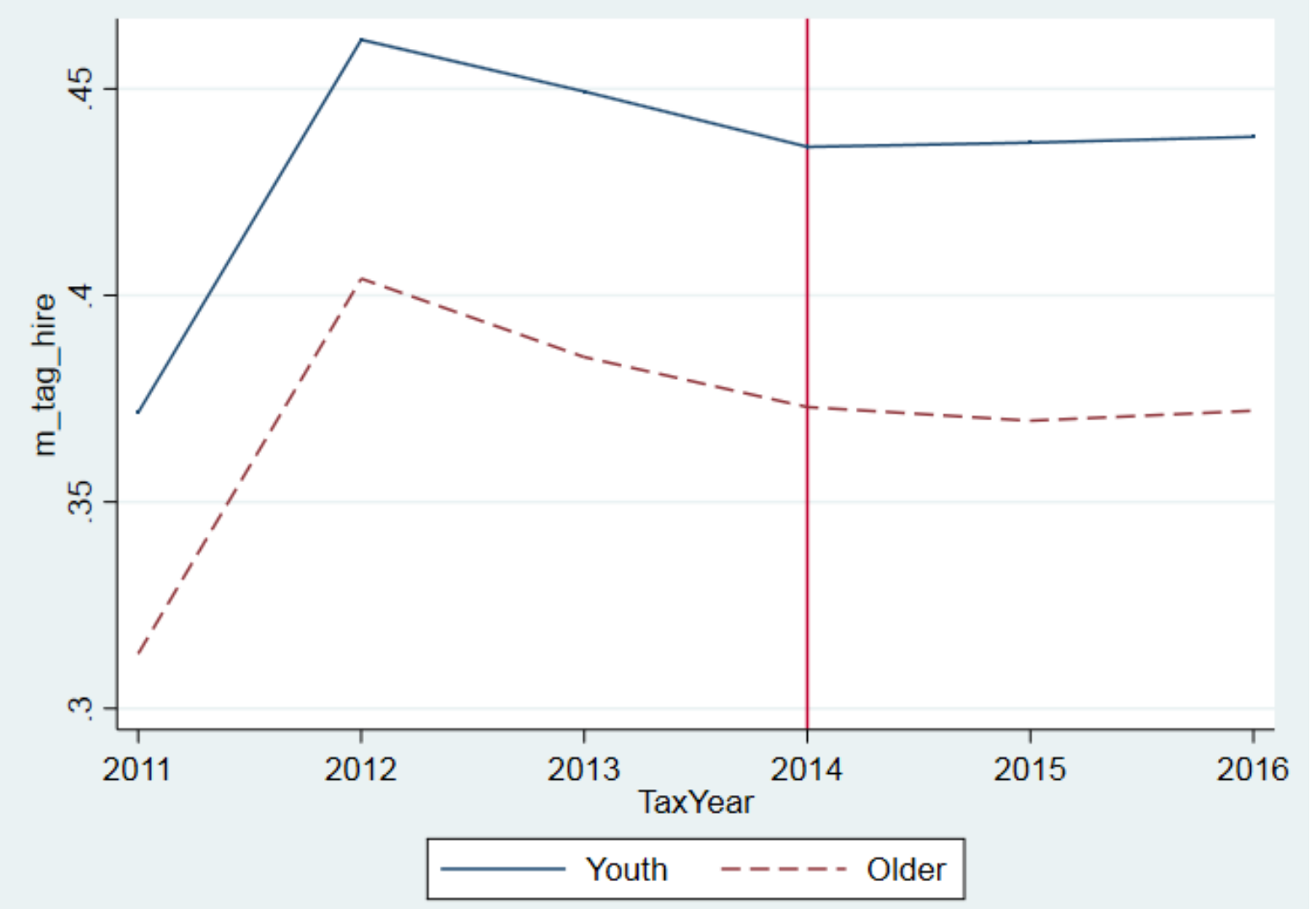

Source: Authors' own estimates using IRP5 data.

We then turn to examine the wage responses more closely. Figure 8 depicts the distribution of wages and changes over time for young and older workers, respectively. It also compares the changes in the wage distribution in a DD manner. While there is wage growth in both groups, the increase in the R2,000-R4,000 range, where the ETI gets its maximum value, is greater for the youth, suggesting that either more jobs have been generated in this area or that wages have increased. Since we can establish whose employers have actually used the ETI, we examine the age distribution by ETI-claiming status. This is investigated in Figure 9, which also depicts the counterfactual wages for young workers based on uprated pre-reform earnings, where the uprating factor is equal to mean wage growth during the period. The results confirm that there is now more mass in the wage distribution for ETI-supported jobs, whereas the distribution of workers has not changed for ETI non-claimers. The increase in the number of jobs for the ETI youth is concentrated at the wage levels close to and above R2,000. 
Table 8: Wage distribution for 25-35-year-olds, 2013 and 2016
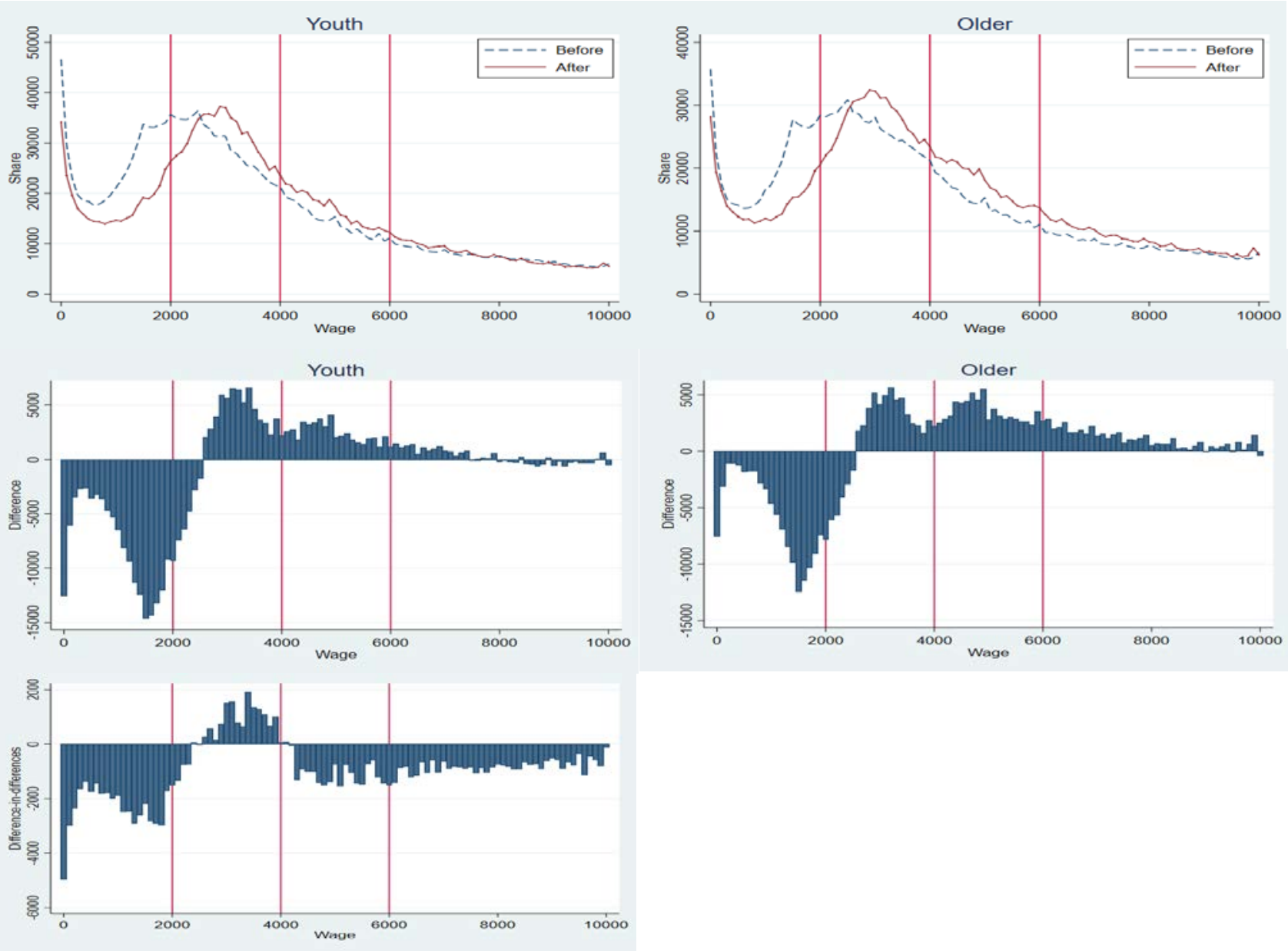

Source: Authors' own estimates using IRP5 data. 
Figure 9: Earnings eligible vs ETI-claimers

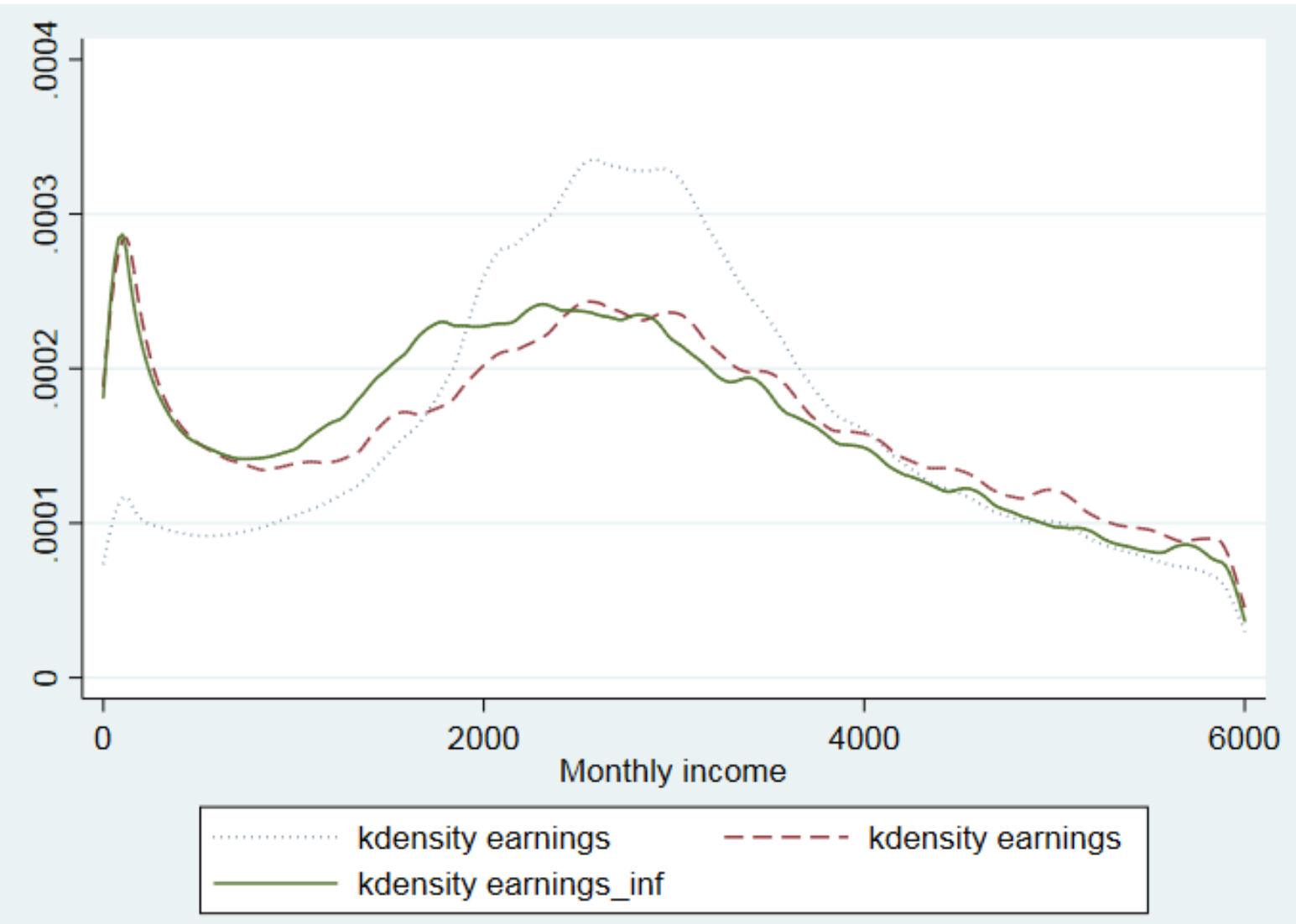

Source: Authors' own estimates using IRP5 data.

We now turn to examine the regression results that stem from the administrative data. There are no increases in the number of jobs or new hires for the target groups (Tables 4 and 5). However, the regression results on earnings (Table 6) indicate that earnings seem to have increased for the treatment group. Thus, somewhat surprisingly, and in contrast to the latest international literature, the incidence on the subsidy is (partly) on workers. 
Table 4: Estimation results on log number of jobs

\begin{tabular}{|c|c|c|c|c|c|c|}
\hline VARIABLES & $\begin{array}{l}\text { (1) } \\
\text { DD }\end{array}$ & $\begin{array}{l}(2) \\
D D+t r e n d s\end{array}$ & $\begin{array}{l}(3) \\
\text { DDD } \\
\end{array}$ & $\begin{array}{l}(4) \\
\text { DDD } \\
\end{array}$ & $\begin{array}{l}\text { (5) } \\
\text { DDD } \\
\end{array}$ & $\begin{array}{l}(6) \\
\text { DDD } \\
\end{array}$ \\
\hline youth_after & $\begin{array}{l}-0.0751 \\
(0.0572)\end{array}$ & $\begin{array}{l}-0.00632 \\
(0.119)\end{array}$ & & & & \\
\hline ddd & & & $\begin{array}{l}0.0845 \\
(0.0567)\end{array}$ & $\begin{array}{l}0.0845 \\
(0.0566)\end{array}$ & & \\
\hline ddd2 & & & & & $\begin{array}{l}0.000117^{*} \\
(6.21 \mathrm{e}-05)\end{array}$ & $\begin{array}{l}0.000117^{*} \\
(6.22 \mathrm{e}-05)\end{array}$ \\
\hline Constant & $\begin{array}{l}7.309 * * * \\
(0.0417)\end{array}$ & $\begin{array}{l}7.265^{\star \star *} \\
(0.0554)\end{array}$ & $\begin{array}{l}6.594^{\star \star *} \\
(0.0198)\end{array}$ & $\begin{array}{l}6.505^{\star \star \star} \\
(0.0281)\end{array}$ & $\begin{array}{l}6.744^{\star \star \star} \\
(0.0267)\end{array}$ & $\begin{array}{l}6.671^{\star \star \star} \\
(0.0379)\end{array}$ \\
\hline Observations & 3,168 & 3,168 & 3,168 & 3,168 & 3,168 & 3,168 \\
\hline R-squared & 0.030 & 0.030 & 0.761 & 0.762 & 0.713 & 0.714 \\
\hline Trends & NO & YES & NO & YES & NO & YES \\
\hline Mean & 7.698 & & 8.412 & & & \\
\hline
\end{tabular}

Notes: The table presents estimation results where the dependent variable is the log of the number of private sector jobs in cells determined by age, gender, and R500 wage interval. Columns (1) and (2) present DD estimates, and (3)-(6) DDD estimates. In columns (1)-(4), the estimate is the coefficient of a dummy variable, whereas columns (5) and (6) present estimates for the actual subsidy value. Columns (2), (4), and (6) add groupspecific trends to the model. The mean is the mean log number of jobs for the target group (youth in columns 1 and 2 and low-wage youth in columns 3-4). Robust standard errors in parentheses. ${ }^{\star \star \star} p<0.01,{ }^{\star \star} p<0.05$, $* p<0.1$.

Source: Authors' own estimates using IRP5 data.

Table 5: Estimation results on entry based on SARS data

\begin{tabular}{|c|c|c|c|c|c|}
\hline VARIABLES & $\begin{array}{l}\text { (1) } \\
\text { DD }\end{array}$ & $\begin{array}{l}\text { (2) } \\
\text { DD+trends }\end{array}$ & $\begin{array}{l}(3) \\
\text { DDD } \\
\end{array}$ & $\begin{array}{l}(4) \\
\text { DDD } \\
\end{array}$ & $\begin{array}{l}5) \\
\text { DDD } \\
\end{array}$ \\
\hline youth_after & $\begin{array}{l}0.00893^{\star \star *} \\
(0.000370)\end{array}$ & $\begin{array}{l}-0.00730^{\star \star \star *} \\
(0.000775)\end{array}$ & & & \\
\hline ddd & & & $\begin{array}{l}-0.00201^{\star \star *} \\
(0.000733)\end{array}$ & $\begin{array}{l}-0.00249 * \star \star \\
(0.000733)\end{array}$ & \\
\hline ddd2 & & & & & $\begin{array}{l}-2.31 \mathrm{e}-06^{\star * *} \\
(8.31 \mathrm{e}-07)\end{array}$ \\
\hline Constant & $\begin{array}{l}0.263^{\star \star \star} \\
(0.000261)\end{array}$ & $\begin{array}{l}-16.97^{\star \star *} \\
(0.310)\end{array}$ & $\begin{array}{l}0.168^{\star \star \star} \\
(0.000320)\end{array}$ & $\begin{array}{l}-8.355^{\star \star \star} \\
(0.371)\end{array}$ & $\begin{array}{l}0.219 * \star \star \\
(0.000310)\end{array}$ \\
\hline Observations & $25,954,489$ & $25,954,489$ & $25,954,489$ & $25,954,489$ & $25,954,489$ \\
\hline R-squared & 0.008 & 0.007 & 0.035 & 0.034 & 0.018 \\
\hline Trends & NO & YES & NO & YES & NO \\
\hline Mean & 0.374 & & 0.436 & & \\
\hline
\end{tabular}

Notes: The table presents estimation results where the dependent variable is an indicator variable of whether the job is a new hire. Columns (1) and (2) present DD estimates, and (3)-(6) DDD estimates. In columns (1)-(4), the estimate is the coefficient of a dummy variable, whereas columns (5) and (6) present estimates for the actual subsidy value. Columns (2), (4), and (6) add group-specific trends to the model. The mean is the mean share of new of jobs for the target group (youth in columns 1 and 2 and low-wage youth in columns 3-4). Robust standard errors in parentheses. ${ }^{\star \star *} p<0.01,{ }^{\star *} p<0.05,{ }^{*} p<0.1$.

Source: Authors' own estimates using IRP5 data. 
Table 6: Estimation results on earnings based on SARS data

\begin{tabular}{|c|c|c|c|c|c|}
\hline VARIABLES & $\begin{array}{l}(1) \\
\text { DD } \\
\end{array}$ & $\begin{array}{l}\text { (2) } \\
\text { DD+trends }\end{array}$ & $\begin{array}{l}(3) \\
\text { DDD } \\
\end{array}$ & $\begin{array}{l}(4) \\
\text { DDD } \\
\end{array}$ & $\begin{array}{l}\text { (5) } \\
\text { DDD } \\
\end{array}$ \\
\hline youth_after & $\begin{array}{l}-791.4^{\star \star \star} \\
(23.59)\end{array}$ & $\begin{array}{l}138.5^{\star \star \star} \\
(50.87)\end{array}$ & & & \\
\hline ddd & & & $\begin{array}{l}452.1^{\star \star *} \\
(55.50)\end{array}$ & $\begin{array}{l}450.8^{\star \star \star} \\
(55.52)\end{array}$ & \\
\hline ddd2 & & & & & $\begin{array}{l}0.614^{\star \star \star} \\
(0.0512)\end{array}$ \\
\hline Constant & $\begin{array}{l}9,373^{\star \star \star} \\
(13.41)\end{array}$ & $\begin{array}{l}8,655^{\star \star \star} \\
(24.80)\end{array}$ & $\begin{array}{l}20,070^{\star \star \star} \\
(26.06)\end{array}$ & $\begin{array}{l}19,287^{\star \star \star} \\
(47.54)\end{array}$ & $\begin{array}{l}16,529 * \star \star \\
(21.81)\end{array}$ \\
\hline Observations & $25,952,068$ & $25,952,068$ & $25,952,068$ & $25,952,068$ & $25,952,068$ \\
\hline R-squared & 0.004 & 0.004 & 0.068 & 0.068 & 0.047 \\
\hline Trends & NO & YES & NO & YES & NO \\
\hline Mean & 7,638 & & 2,776 & & \\
\hline
\end{tabular}

Notes: The table presents estimation results where the dependent variable is earnings. Columns (1) and (2) present DD estimates, and (3)-(5) DDD estimates. In columns (1)-(4), the estimate is the coefficient of a dummy variable, whereas column (5) presents estimates for the actual subsidy value. Columns (2) and (4) add groupspecific trends to the model. The mean is the earnings for the target group (youth in columns 1 and 2 and lowwage youth in columns $3-4)$. Robust standard errors in parentheses. ${ }^{\star \star \star} p<0.01,{ }^{\star \star} p<0.05,{ }^{*} p<0.1$.

Source: Authors' own estimates using IRP5 data.

\section{Conclusion}

The analysis so far suggests that the subsidy may have increased the earnings of those in the target group, implying that the incidence of the subsidy was partly on the employees. However, the policy has not led to a systematic improvement in employment for the target population, which has been the main goal of the programme. We have just obtained two more years of data, up to 2018, for the payroll records and expect the PALMS 3.3 to be released very soon. With this greater number of observations, we are currently investigating whether the system led to better employment during the period when it became better known. In addition, we will be concentrating on the employment impacts on the youngest workers (18-24-year-olds), among whom the take-up is the greatest. We will also carry out heterogeneity analyses by gender and by industry, where the main interest is in the sectors where the policy has been used the most. 


\section{References}

Altbeker, A., S. Schirmer, and A. Bernstein (2007). 'Routes into Formal Employment: Public and Private Assistance to Young Job Seekers'. CDE Focus. Johannesburg: The Centre for Development and Enterprise.

Bernstein, A., A. Altbeker, and A. Johnston (2016). 'The Growth Agenda: Priorities for Mass Employment and Inclusion. Skills'. The CDE Growth Agenda Series. Johannesburg: The Centre for Development Enterprise.

Cahuc, P., S. Carcillo, and T. Le Barbanchon (2018). 'The Effectiveness of Hiring Credits'. The Review of Economic Studies, 86(2): 593-626.

Ebrahim, A., M. Leibbrandt, and V. Ranchhod (2017). 'The Effects of the Employment Tax Incentive on South African Employment'. WIDER Working Paper 2017/5. Helsinki: UNUWIDER.

Gruber, J. (1997). 'The Incidence of Payroll Taxation: Evidence from Chile'. Journal of Labor Economics, 15(3): 72-101.

Heintz, J., and S. Bowles (1996). 'Subsidising Employment. Wage Subsidies and Job Creation'. In J. Baskin (ed.), Against the Current: Labor and Economic Policy in South Africa. Randburg: Naledi.

Kerr, A., D. Lam, and M. Wittenberg (2017). 'Post-apartheid labour market series' [dataset]. version 3.2. Available at:

https://www.datafirst.uct.ac.za/dataportal/index.php/catalog/434/accesspolicy (accessed 9 July 2018).

Lewis, J.D. (2001). 'Policies to Promote Growth and Employment in South Africa'. Discussion Paper 16. Washington, DC: The World Bank.

Pollin, R., G. Epstein, J. Heintz, and I. Ndikumana (2009). 'An Employment-targeted Economic Program for South Africa'. In T. Mckinley (ed.), Economic Alternatives for Growth, Employment and Poverty Reduction. London: Palgrave Macmillan.

Ranchhod, V., and A. Finn (2015). 'Estimating the Effects of South Africa's Youth Employment Tax Incentive: An Update'. SALDRU Working Paper 2015-8. Cape Town: SALDRU.

Saez, E., M. Matsaganis, and P. Tsakloglou (2012). 'Earnings Determination and Taxes: Evidence from a Cohort-based Payroll Tax Reform in Greece'. The Quarterly Journal of Economics, 127(1): 493-533.

Saez, E., B. Schoefer, and D. Seim (2019). 'Payroll Taxes, Firm Behavior, and Rent Sharing: Evidence from a Young Workers' Tax Cut in Sweden'. American Economic Review, forthcoming.

Smith, C. (1993). 'International Experience with Worker-side and Employer-side Wage and Employment Subsidies, and Job Search Assistance Programmes: Implications for South Africa.' Employment Growth and Development Initiative. Pretoria: HSRC

Visser, M., and G. Kruss (2009). 'Learnerships and Skills Development in South Africa: A Shift to Prioritise the Young Unemployed'. Journal of Vocational Education \& Training, 61(3): 357-74. 